\title{
1. Retailing and consumer demand for convenience
}

\author{
Bart J. Bronnenberg
}

\subsection{INTRODUCTION}

Retailing is an important sector of the economy. It is part of the distributive trades composed of all the institutions involved in the distribution of products from manufacturers to consumers. The existence of a large distribution sector is a natural consequence of the separation of consumers from producers that comes with manufacturing at large volume (Braithwaite and Dobbs 1932) and it is an important and a necessary part of our industrial organization. Among the earliest business or economics scholars interested in retailing and distribution is Shaw (1912), who writes

the problems of market distribution are no less worthy of systematic study than are the problems of factory production. It is as essential that the finished goods be moved from the stock room of the producer to the hands of the consumer, as it is that operations be performed upon the raw material to produce the finished goods. (Shaw 1912, emphasis added)

The essence of the distribution sector translates into its prominent size. Using the data from the first census of the U.S. Distribution sector in 1929, Malenbaum (1941) estimated that the share of distribution in the final price of manufactured goods was about 51 percent. The prominence of distribution in today's economy is equally obvious. Using the United Nations National Accounts database, ${ }^{1}$ Table 1.1 shows the 2004 and 2013 size of the wholesaling and retailing sector relative to the size of the manufacturing sector for China, a composite of other BRICS Nations, the United States and Western Europe. Retailing and wholesaling account for 12-17 percent of 2013 GDP. This is net of the transportation sector, which typically adds another 4-5 percent. Furthermore, the ratio between the output in wholesaling plus retailing and the output manufacturing is quite high at values close to 1 (with the exception of China). The tables at the UN confirm that this ratio extends to the value added in the distribution sector versus the manufacturing sector. Also noteworthy, the size of the retail sector increases between 2004 and 2013, especially in the emerging economies of the BRICS nations, suggesting an expansion of retail 
Table 1.1 Size of the retail sector in international perspective

\begin{tabular}{|c|c|c|c|c|c|c|c|c|}
\hline \multirow{2}{*}{$\begin{array}{l}\text { Country } \\
\text { Year }\end{array}$} & \multicolumn{2}{|c|}{ China } & \multicolumn{2}{|c|}{$\begin{array}{l}\text { Other } \\
\text { Brics }\end{array}$} & \multicolumn{2}{|c|}{$\begin{array}{l}\text { United } \\
\text { States }\end{array}$} & \multicolumn{2}{|c|}{$\begin{array}{l}\text { Western } \\
\text { Europe }\end{array}$} \\
\hline & 2004 & 2013 & 2004 & 2013 & 2004 & 2013 & 2004 & 2013 \\
\hline $\begin{array}{l}\text { Manufac- } \\
\text { turing }\end{array}$ & 625 & 2741 & 340 & 789 & 1619 & 2029 & 1100 & 1389 \\
\hline $\begin{array}{l}\text { Wholesale + } \\
\text { Retail }\end{array}$ & 195 & 1084 & 348 & 1108 & 1506 & 1970 & 873 & 1125 \\
\hline GDP & 1945 & 9181 & 2199 & 6644 & 12275 & 16768 & 6691 & 9101 \\
\hline $\begin{array}{l}\text { Distribution/ } \\
\text { GDP }\end{array}$ & $10.0 \%$ & $11.8 \%$ & $15.8 \%$ & $16.7 \%$ & $12.3 \%$ & $11.7 \%$ & $13.0 \%$ & $12.4 \%$ \\
\hline $\begin{array}{l}\text { Distribution/ } \\
\text { Manufac- } \\
\text { turing }\end{array}$ & $31.1 \%$ & $39.6 \%$ & $102.3 \%$ & $140.3 \%$ & $93.0 \%$ & $97.1 \%$ & $79.3 \%$ & $81.0 \%$ \\
\hline
\end{tabular}

Notes: Numbers refer to Billions of 2013 US dollars. Data are from the United Nations National Accounts database available at https://unstats.un.org/unsd/snaama/Introduction. asp.

services there. These numbers demonstrate the retail sector is prominent and roughly equal in size to the manufacturing sector, ${ }^{2}$ thus interestingly supporting Shaw's (1912) conjecture about the relative importance of distribution compared to manufacturing.

Why do economies have such a large retail sector and what does it produce? In this chapter, I explore this question to some extent by looking at the retail sector through the lens of household production theory (Becker 1965). The "new" consumer theory of the 1960s viewed the household as an economic unit that produces consumption goods at home by combining products purchased in the market with time input from the household. The theory's defining assumptions are that time is a scarce resource and the household allocates it deliberately to maximize utility. Developments like ongoing urbanization, time pressure from dual work schedules, and shifts in the demand for leisure have made household time allocation and the role of market institutions a relevant topic.

Household time allocation has a large impact on (1) the consumer or household problem and (2) the role of the retailer in it. First, the optimal allocation of time affects the household problem in various ways. To start, a household can supply time to the labor market to generate income. This affects the consumer's consumption problem because, everything else equal, supplying more labor means earning more income and shifting out the income constraint. Next, a household can supply time to work at 
home, that is, to home production of consumption goods. This generally affects the variety and time intensity of input goods bought in a supermarket. Finally, time itself can also be consumed as leisure. Consequently, the nature of the optimal allocation of time is an important determinant of households' purchasing and consumption behavior.

Second, the allocation of time affects how one views the effect of retailing on the consumer problem. Retailers offer services that improve efficiency in household production, such as distribution and assortment selection. Through the lens of the new consumer theory, retailing can be seen as a technology that shifts certain costs of home production and of purchasing (or using the market) from consumers to sellers (for a related understanding, see also, e.g., Betancourt 2004). Thus, the perspective taken in this chapter is that retailing is a technology (1) to make purchasing easier by means of offering convenient distribution and transaction, and (2) to improve efficiency of home production through its assortment selection task.

Using this orientation, I aim to discuss in this chapter how structural changes in the time allocations of consumers impact retail strategy, and conversely, how retail innovations that make purchasing and home production more convenient impact the purchasing habits and time use of consumers. A second goal of this chapter is to connect the marketing literature on retailing to the economic literatures on household economics and on time use.

The structure of this chapter is as follows. I first review, in section 1.2, how time costs in home production impact demand for market goods and for the convenience of obtaining them. I propose a simple taxonomy of consumer time-costs in home production. I next identify, in section 1.3, how a structural change in consumer demand for more convenience and for more efficient inputs to home production, has led to several long-term trends in retailing. Next, in the following two sections, I review two types of adjustment to these trends. First, in section 1.4, I discuss how retail innovations and demand for more convenience have impacted manufacturers. Second, in section 1.5, I circle back to the consumer problem and discuss the body of literature that reflects on how marketization of home production by retailers and other institutions has affected households' time allocations. For reference, see Figure 1.1. Section 1.6 closes with suggestions for future research into the role of consumer time use on innovation in retailing and vice versa. 


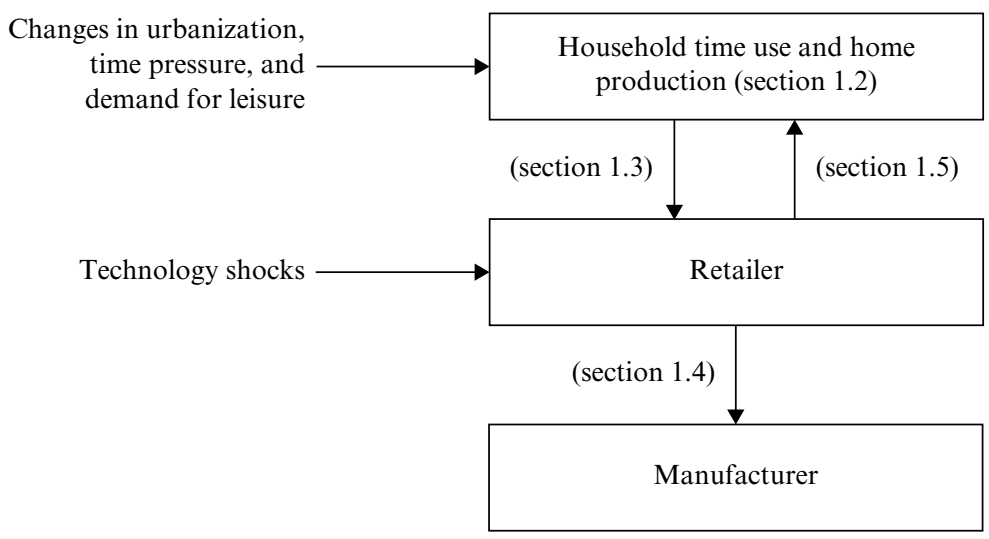

Figure 1.1 Overview of the chapter

\subsection{CONSUMER DEMAND AND TIME USE}

\subsubsection{How Do Consumers Use Time?}

There is a large literature in economics on how consumers use time. Hamermesh et al. (2005) present a comprehensive review of this literature on so-called time use surveys. Time use surveys go back to at least the 1920s. In a typical implementation, a time use survey interviews a cross section of respondents on how they spent the previous 24 hours. An analyst then codes the recorded activities to a pre-set scheme of different activities organized in tiers. For instance, the American Time Use Survey (ATUS) uses a tier-one scheme that includes 17 different activities such as "personal care," "education," or "household services." Lower tier activities are progressively more specific. For example, "personal care" consists of sub-categories like "sleeping," "grooming," etc.

Relevant in the context of retailing and distribution, I now report on some results from time use surveys on home production of food (including shopping) and transaction costs of purchasing food items. In particular, I compiled how much time consumers spend on (1) shopping plus shoppingrelated travel, (2) food preparation, and (3) consumption of food. Using the Harmonized European Time Use Survey, ${ }^{3}$ Table 1.2 shows time allocations in hours and minutes per day specific to country, activity participation status, and gender for a cross-section of 15 European nations.

Table 1.2 demonstrates that time allocations to buying, preparing, and consuming food are consistently high across each of the 15 included European nations. For instance, conditional on participation in food 


\begin{tabular}{|c|c|c|c|c|c|c|c|c|c|c|c|}
\hline 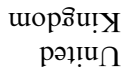 & & 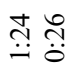 & $\stackrel{⿱ 亠}{0}$ & $\stackrel{0}{\ddot{0}}$ & $\stackrel{\overbrace{}}{\ddot{n}}$ & & 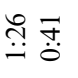 & $\stackrel{m}{-}$ & 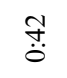 & $\stackrel{n}{n}$ & \\
\hline иәрәмS & & 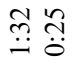 & $\stackrel{\check{0}}{\ddot{0}}$ & $\frac{0}{\ddot{\theta}}$ & $\stackrel{n}{\sim}$ & & 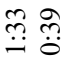 & $\stackrel{?}{n}$ & $\stackrel{0}{m}$ & $\stackrel{m}{m}$ & \\
\hline u!̣eds & & 亲 $\frac{\hat{\theta}}{\dot{0}}$ & $\frac{a}{0}$ & $\grave{o}$ & $\stackrel{\widetilde{n}}{\stackrel{n}{1}}$ & & 守尔 & $\stackrel{n}{-}$ & $\stackrel{?}{0}$ & $\stackrel{ }{\ddot{\gamma}}$ & \\
\hline в!ฺәムOIS & & $\stackrel{m}{=} \stackrel{0}{\ddot{0}}$ & $\frac{0}{\ddot{\theta}}$ & $\overline{\ddot{\theta}}$ & $\stackrel{\circ}{\ddot{i}}$ & & $\stackrel{m}{\stackrel{9}{*}}$ & $\stackrel{n}{0}$ & $\stackrel{m}{0}$ & $\stackrel{n}{n}$ & \\
\hline pur $I^{\circ} d$ & & 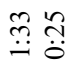 & $\ddot{\check{o}}$ & $\frac{\Delta}{\ddot{\theta}}$ & $\stackrel{m}{\ddot{n}}$ & & $\stackrel{m}{\stackrel{m}{\rightarrow}} \stackrel{?}{0}$ & $\tilde{n}$ & $\stackrel{\mathscr{T}}{\circ}$ & $\stackrel{n}{m}$ & \\
\hline KEM.JON & & 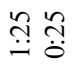 & $\ddot{\sigma}$ & $\frac{m}{0}$ & $\stackrel{\leftrightarrow}{i}$ & & $\stackrel{\overbrace{}}{\dddot{n}} \stackrel{0}{=}$ & $\stackrel{1}{\oplus}$ & $\stackrel{\oplus}{0}$ & $\stackrel{n}{m}$ & \\
\hline в!̣uеnપı!า & & 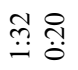 & $\frac{m}{0}$ & $\frac{m}{0}$ & $\stackrel{\infty}{\ddot{i}}$ & & 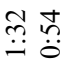 & $\ddot{7}$ & $\stackrel{\square}{\circ}$ & $\stackrel{g}{\dot{m}}$ & \\
\hline 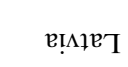 & & $\stackrel{m}{=} \underset{0}{\ddot{0}}$ & $\frac{N}{\ddot{\theta}}$ & $\frac{1}{0}$ & $\frac{m}{\ddot{i}}$ & & $\stackrel{m}{\stackrel{m}{\rightarrow}} \stackrel{\sim}{0}$ & $\underset{7}{\ddot{0}}$ & $\stackrel{\sharp}{0}$ & $\underset{\dot{m}}{\stackrel{J}{+}}$ & \\
\hline$\left.\kappa_{[}+\mathcal{I}\right]$ & & $\stackrel{n}{n}=$ & તָ & $\stackrel{\sim}{\ddot{0}}$ & $\stackrel{\stackrel{\sim}{*}}{i}$ & & ڤn & & $\stackrel{\infty}{m}$ & $\stackrel{\circlearrowright}{\ddot{\forall}}$ & \\
\hline Киеш..ə⿹ & & $\stackrel{?}{\stackrel{9}{-}} \underset{0}{\ddot{0}}$ & $\stackrel{\overbrace{}}{0}$ & $\frac{0}{\ddot{\theta}}$ & $\stackrel{\text { i }}{\dot{J}}$ & & 导芯 & $\stackrel{\hat{o}}{-}$ & $\stackrel{m}{\oplus}$ & $\stackrel{g}{\dot{f}}$ & \\
\hline อ૦U२.I & & $\stackrel{\infty}{\ddot{i}} \underset{0}{\ddot{0}}$ & 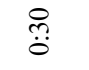 & $\stackrel{m}{\ddot{\theta}}$ & $\underset{\ddot{m}}{\bar{m}}$ & & $\begin{array}{l}\infty \\
\ddot{i} \\
\dot{0}\end{array}$ & $\stackrel{\infty}{\dddot{I}}$ & ஸे & 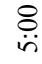 & \\
\hline рuг[u! & & $\stackrel{\overbrace{}}{\ddot{\theta}}$ & $\stackrel{\overbrace{}}{0}$ & 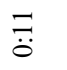 & $\vec{\sim}$ & & 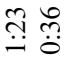 & $\tilde{n}$ & 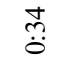 & $\stackrel{\text { in }}{i}$ & \\
\hline 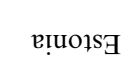 & & $\stackrel{\vartheta}{\ddot{-}} \ddot{0}$ & 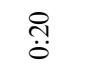 & $\stackrel{m}{\ddot{\theta}}$ & $\stackrel{m}{\ddot{n}}$ & & $\stackrel{9}{\dddot{g}}$ & $\ddot{n}$ & $\stackrel{m}{\oplus}$ & ले & \\
\hline ห!̣toิ|ng & : & 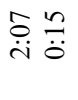 & $\frac{m}{\ddot{0}}$ & $\stackrel{7}{\ddot{0}}$ & $\stackrel{\text { ণ̃ }}{i}$ & .ే & $\hat{i} \dot{i}$ & $\stackrel{?}{0}$ & 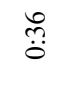 & 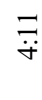 & \\
\hline un!़े|ग्व & & 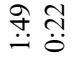 & 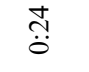 & $\frac{0}{0}$ & $\vec{n}$ & $\stackrel{\text { : }}{\stackrel{0}{\vec{c}}}$ & 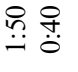 & $\hat{n}$ & $\underset{\oplus}{\ddot{0}}$ & $\stackrel{\infty}{\stackrel{\leftrightarrow}{\dot{f}}}$ & \\
\hline & 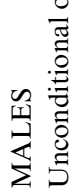 & $\stackrel{\infty}{\Xi}$ & 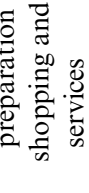 & 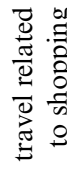 & 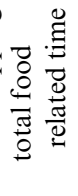 & 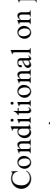 & 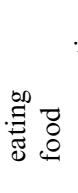 & 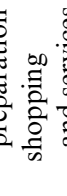 & 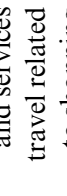 & & \\
\hline
\end{tabular}




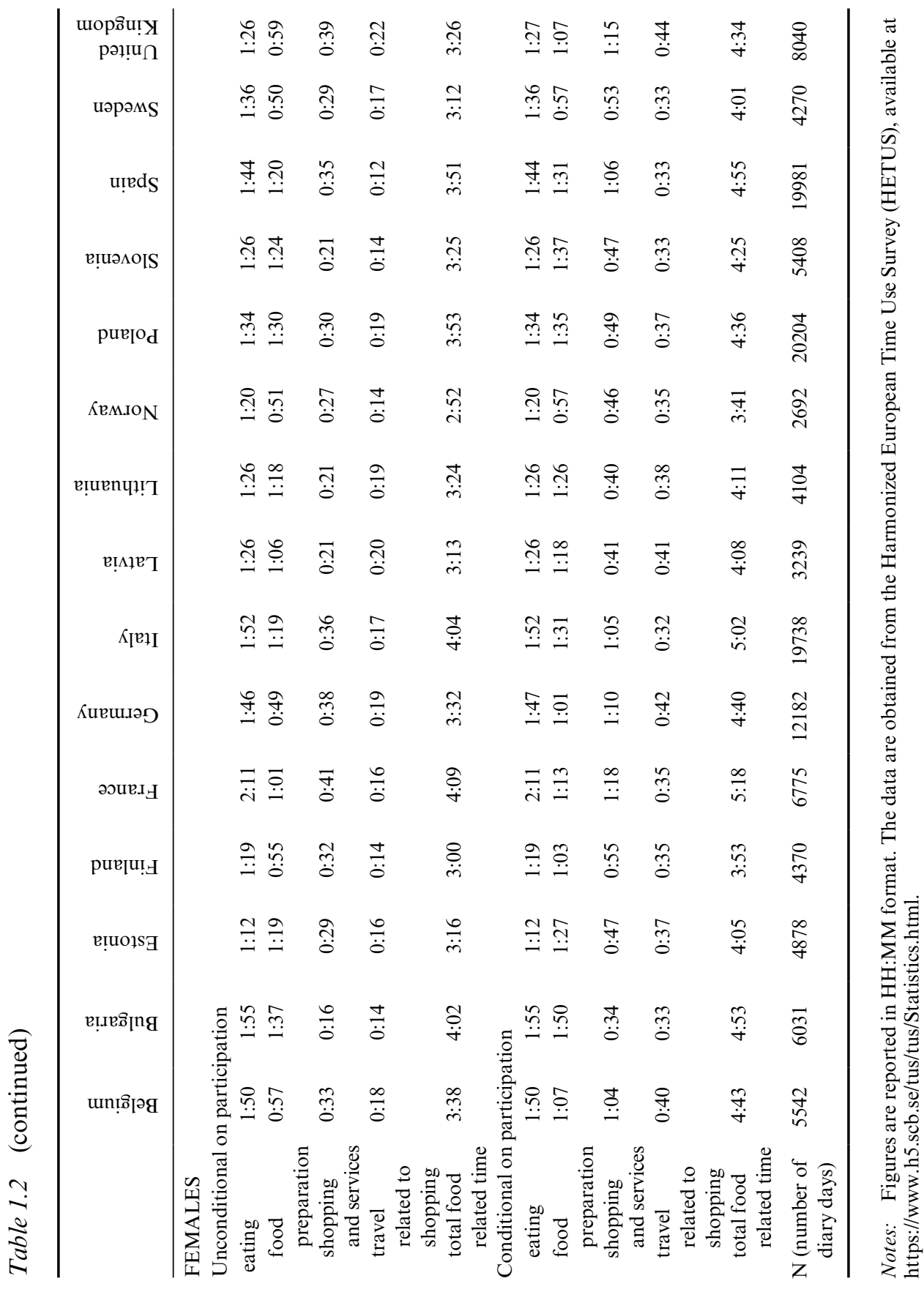


purchase, European males spend about 54 minutes a day shopping (55 minutes for women), and incur about 39 minutes of travel time to the store (36 for women). Given participation, both sexes spend about an hour on food preparation but participation is heavily concentrated in women. To illustrate, unconditionally on engaging in food preparation, an Italian male spends 11 minutes preparing food whereas an Italian female does so for 1 hour and 19 minutes. Even given participation, the differences are substantial: on average across nations, women spend 1 hour and 20 minutes and men 42 minutes on food preparation.

The total, unconditional, time allocated to food-related activities (including consumption) is substantial at 2 hours and 33 minutes for males and 3 hours and 31 minutes for females. Assuming allocation of about 8 hours in each day to sleep, consumers allocate just short of 20 percent of their available time to home production of food (including procurement). ${ }^{4}$

It is important to realize that the time use numbers quoted from the Harmonized European Time Use Surveys are representative of the situation in 2007. Cutler et al. (2003) report that food preparation and cleaning activities afterwards took U.S. households more than 2 hours a day in 1965 whereas in 1995 it had reduced to half of this (the latter is close to the European numbers on food preparation in 2007). If the same trend applies to Europe, time use for food related activities was traditionally much more than 20 percent of available time. These numbers imply that current time allocation to food-related activities is substantial but recent decades have witnessed some replacement of time allocated to home production. In the next sections, I will argue that distribution services and assortments of less time intensive market goods have been an important contributing factor to this replacement.

\subsubsection{Time Use and the "New Consumer Theory"}

The idea that time is a fundamental constraint in the economics of the household dates back to at least Becker (1965). In Becker's theory, households receive utility $U\left(Z_{1}, \ldots, Z_{J}\right)$ from quantities $Z_{1}, \ldots, Z_{J}$ of consumption goods $j=1, \ldots, J$. Each of the consumption goods $Z_{j}$ is produced according to a home production function, $Z_{j}=f\left(\mathrm{x}_{j}, T_{j}\right)$, that combines quantities of market goods, bundled in a vector $x_{j}$, with quantities of time $T_{j}$. Market goods, for example purchased in a grocery store, are thus different from consumption goods in the sense that it requires time to convert a bundle of one into the other.

If we denote the prices for market goods by $p_{j}$ and the value for time by $w_{j}$ (for instance, the wage rate) then the household problem can be expressed 
as maximizing utility $U\left(Z_{1}, \ldots, Z_{J}\right)$ subject to a budget constraint in which income and time are substitutes. In particular, the household problem is

$$
\max _{x, T} U\left(Z_{1}, \ldots, Z_{J}\right) \text { such that } \Sigma_{j} p_{j} x_{j}+w_{j} T_{j} \leq S .
$$

The left hand side of the full budget constraint, $\Sigma_{j} p_{j} x_{j}+w_{j} T_{j} \leq S$, takes two arguments, namely the total expenditure on market goods $p_{j} x_{j}$ and the money value of the time spent on home production $w_{j} T_{j}$. The total of these two components cannot exceed total income $S$, which is thought of as fixed. For instance, if $w_{j}$ is the wage and applicable to all the time units available to the consumer, then the full income equals total wages earned from working in the market all the time.

Hours worked in home production, $\Sigma_{j} T_{j}$, are excluded from supply to the labor market and earning income. More work at home means less work in the labor market and, ceteris paribus, less income. Because of this property, Becker's (1965) new consumer theory unifies Marshallian demand functions for market goods, $x_{j}\left(p_{j}\right)$, with choices about how much labor to supply to the market and to home production. Gronau (1977) expanded Becker's (1965) framework of consumers' time use and consumption by adding leisure to the household consumption problem.

Another aspect of household behavior that is important to consider in the context of retailing is variety of home production. Dixit and Stiglitz (1977) considered consumers with a love of variety. In terms of the utility function $U\left(Z_{1}, \ldots, Z_{J}\right)$ this simply means that utility is increasing in the number of consumption goods $J$ holding constant their total quantity $\sum_{j=1}^{J} Z_{j}$. As demonstrated in Dixit and Stiglitz's paper, a constant elasticity of substitution (CES) utility function has this property.

Why are time-allocation models useful in the study of the retailing sector? Factors such as dual labor participation, busy work schedules, urbanization and changing consumption habits have increased the value of time to the consumer. The short answer pursued in this chapter is that these trends have reduced the availability of time spent at home and created demand for services that lower the time intensity of home production, even at raised prices for market goods.

Indeed, applied to the context of retailing, the new consumption theory of Becker (1965) and Gronau (1977) tells us that the full price for a consumption-good includes both pecuniary and time costs. ${ }^{6}$ Becker's (1965) and Gronau's (1977) theory are in fact fundamental to understanding a major benefit of retailing to consumers and to understanding the effect of retailing on demand for market goods. Retailing is namely a technology that lowers the time cost of purchasing and using the market. In terms of Becker (1965) and Gronau (1977), one might say that retailing aims to 
lower the full price of consumption goods by increasing productivity in the home production of consumption goods. In fact, it is probably no exaggeration to state that a comprehensive understanding of the function of marketing and retailing is simply impossible without taking into account their effects on the full (time plus money) cost of home production and instead focusing on pecuniary prices alone.

\subsubsection{The Home Production Function}

In the home production function $Z_{j}=f\left(x_{j}, T_{j}\right)$, quantities of consumption goods $Z_{j}$ are produced using quantities of market goods $x_{j}$ and time allocations $T_{j}$ as inputs. In this section, I speculate on the shape of this production function, and later show how this shape predicts certain purchase patterns routinely observed in household purchase data.

First, the relation between quantities of home production time and quantities of the consumption good can and will generally have a threshold $T_{0}$ below which time allocation is ineffective. This threshold is thus a fixed time cost of home producing a quantity $Z$ of the consumption good. I will argue below that time thresholds of various kinds are ubiquitous and an important reason for the existence of retailers.

Input thresholds in the home production function are obviously not restricted to time. They apply equally to capital or money. For instance, producing a meal even at small quantities, generally requires owning appliances like a stove or a refrigerator (which could be interpreted as capital goods to home production). To shop for products, even at small quantities one needs, for example, a car to visit a brick-and-mortar store or a computer to visit an online store, and so on.

Second, beyond the threshold, the relation between time inputs and quantities of consumption goods can, in principle, have any shape and reflect additional economies of scale from, for example, learning by doing. More likely, the relation between inputs $x$ and $T$ and quantities $Z$ of consumption goods, beyond the input threshold, is concave. I speculate that such a relation arises from the idea that, holding, for example, the quantity of market goods $x$ fixed, more time will produce decreasingly more quantity of consumption goods.

Figure 1.2 shows that the presence of time thresholds in home production taken together with decreasing marginal productivity beyond this threshold suggest that the relation between time inputs and quantities of consumption goods may be S-shaped.

If the production function is S-shaped in time inputs, that is, as in Figure 1.2, then the per-quantity time costs of consumption goods are not only dependent on their nature but also its quantity. In particular, 


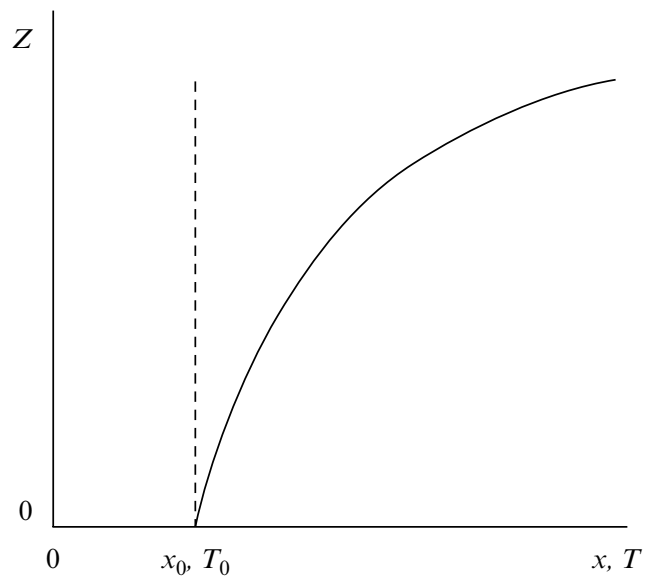

Figure 1.2 Home production function - fixed and variable inputs

the time cost of a unit of the consumption good first falls with household output, from amortization of the fixed input or threshold $T_{0}$ across a larger quantity $Z$ of the consumption good, and then rises, from decreasing marginal productivity. Purchase behavior for those market goods that are inputs to the consumption good obviously depends on the economies of scale implied by the S-shaped response in home production and the threshold $T_{0}$ in the home production function. For instance, if the consumption good requires some fixed time cost of preparation or purchase that adds to the threshold $T_{0}$, this creates an economy of scale in quantity that predicts purchase quantity thresholds (see Huang and Bronnenberg 2017).

\subsubsection{A Taxonomy of Fixed Time Costs in Home Production}

Betancourt (2004) identifies several costs incurred by consumers to carry out their purchasing and consumption activities. Among these are time and travel costs, psychological costs, storage costs, search costs, etc. With the possible exception of storage, often these costs have fixed (to quantities) components.

Time thresholds, $T_{0}$, in home production are a net cost to consumers. They result in utility losses because (1) less time is left for productive activities, and (2) input thresholds create economies of scale in quantity, which in turn result in a loss of variety in home production. To organize the literature by how retailing responds to changes in consumers' value of time or changes in retailers' technological environment, I propose a 
common-sense taxonomy of these fixed costs as they relate to different tasks in home production:

(1) Cost of travel (incurred per trip): Home production requires going to a store. When visiting a store is costly in terms of travel time, consumers will economize and only travel to the store when the basket size is large enough to amortize the travel cost (Bell et al. 1998). Travel or store-trip costs are mostly fixed to the quantity and to the variety of the shopping basket. One of the consequences of fixed trip costs, is that as the shadow price for time drops over the life cycle of the consumer, households shop more often. In dynamic price environments, for example, with many promotions, fixed trip costs are therefore often associated with paying higher prices from the lack of shopping frequency. Alternatively, when retailers offer unique assortments, fixed trip costs can imply shopping at fewer stores, which reduces variety in consumption.

(2) Cost of evaluation (incurred per market-good): The cost of evaluating products in the store is a fixed (to quantity) cost that limits the demand for variety, just like price limits the demand for quantity. For instance, if different varieties of market goods are costly (in terms of time) to evaluate or purchase, even a consumer with a love of variety will substitute away from variety and into quantity. Thus, evaluation costs impact whether there are corner solutions in the maximization problem in equation (1.1). This effect will be larger the less differentiated products are. In this context, Bronnenberg (2015) models "per-product" purchasing or evaluation costs and shows how they suppress the demand for variety. Huang and Bronnenberg (2017) study such evaluation costs empirically. They show that the economies of scale implied by evaluation costs create purchase quantity thresholds away from 0 . That is, per-product evaluation costs make buying at small quantities unattractive. Identifying the cost of evaluation from the size of the observed quantity thresholds, Huang and Bronnenberg (2017) report estimates that imply such evaluation costs are large.

(3) Cost of preparation (incurred per consumption good): A final important fixed cost in home production takes place at the level of consumption goods, for example, from learning about new recipes or even cooking a familiar one. ${ }^{7}$ Preparation cost not only affects the amount of variety purchased, but also its nature; in particular the time intensity of the consumption goods produced at home. For instance, Bronnenberg et al. (2017) find that consumers who generally have a lower value for time, for example retirees, will purchase more 
time intensive categories and fewer processed foods. Gronau and Hamermesh (2008) report a similar finding in the context of time intensive and goods intensive activities.

With time being an important input to the quantity, variety, and nature of consumption, I will now review the economic and marketing literature on how retailing in the grocery sector has diminished these consumer thresholds of time inputs, through format modernization, added services, and assortment selection.

\subsection{RETAILING TRENDS IN PROVIDING CONVENIENCE}

\subsubsection{Empirical Support for Cost Shifting}

Becker's (1965) theory of home economics focuses on time use and home production. Indirectly, it implies demand for low time-input or "convenient" market goods. In this section, I review the literature on how retailers respond to shifts in consumer demand for convenience or shifts in technology to cater to this demand. Structural changes in demand for convenience have been brought on by urbanization, dual labor participation, and tighter work schedules, etc. (Freeman et al. 2005; Ngai and Pissarides 2008). Changes in technology to cater to demand for convenience include IT-enabled tracking of consumers, stock-keeping, delivery, etc. Continuing to focus on the cost-shifting role of retailers (Betancourt 2004), I organize the discussion by using the taxonomy of time costs just outlined and ask how retailers have changed the consumer time cost from (1) traveling to stores, (2) evaluating and locating market goods, and (3) preparing consumption goods.

According to Buera and Kaboski (2012) the dramatic rise of the service industry during the past century is a testimony to the idea that consumers appreciate saving time and are willing to pay for convenience. Empirically, Pryor (1977) is among the first to study the cost-shifting role of retailers. Studying how retailers offset purchasing costs (or other home production costs) ideally involves contrasting markets with retailing and counterfactual markets without it, holding everything else constant, for example, measuring the impact of retailing against the counterfactual of consumers purchasing products directly from manufacturers (i.e., with consumers incurring the cost of using the market and of home production). Unfortunately, such a counterfactual does not exist. Instead, Pryor (1977) focuses on the contrast between market economies (e.g., 
the United States), where commerce functions are well developed, and centrally planned economies (e.g., the former Soviet Union), where they are not. He finds that the labor costs in retailing and wholesale are lower in planned economies than in market economies but consumers invest more time (labor) shopping for foods. Remarkably, these differences cancel out in Pryor's (1977) study. That is, the total labor time spent on moving products from manufacturers to consumers is roughly equal across planned and market economies. However, the cost of using the market, that is, the cost of distribution, wait time, etc., is shifted from consumers toward retailers in market economies.

Cutler et al. (2003) report that the time allocation to food preparation and cleaning activities afterwards has been halved between 1965 and 1995 while marketization of home production has increased. This and Pryor's (1977) study suggest a long-run trend in retailing of shifting the cost of purchasing and home production from consumers to producers.

Cost shifting obviously does not mean that the retailer should take on the full cost of distribution. Indeed, in finding the lowest total cost or full price of consumption goods to consumers, the consumer may still have to make a significant purchase and preparation effort. For example, Johnson and Romeo (2000) present the case where gasoline retailers have put into place self-service stations, making it easy for consumers to use the time they would otherwise be idling (while the gas-attendant fills up the tank) to perform the service themselves. The benefits of this are reported to be that consumers living in states with self-service options enjoy lower gas prices, and more entry of tie-in convenience stores compared to states with a ban on self-service.

\subsubsection{Lowering the Cost of Travel}

I now review empirical support for shifting store travel costs, purchasing costs of market goods, and preparation costs of consumption goods from consumers to retailers.

Arguably the most obvious purchasing cost of market goods, or cost of using the market in general, is the time associated with going to the store or market. ${ }^{8}$ Business models based on shifting consumer travel costs to retailer distribution cost have been around for a long time. For instance, in the context of household time use, mail order or catalog companies convert consumer travel time to freight costs. Mail order companies were first introduced in the seventeenth century in Great Britain and have been popular in the United States since the mid-nineteenth century. Early entrants included entrepreneurs like Aaron Montgomery Ward in 1872 and Richard Warren Sears in 1888. ${ }^{9}$ Mail order companies were a great 
channel, especially, for products with low demand from consumers and high entry costs for retailers. These conditions favor the situation where stores need to cover a large market area to start a business (see also, e.g., Balasubramanian 1998) and the average distance between consumers and sellers is large.

Alternatively, retailers lower the consumer's travel costs through entry and format strategies. Ellickson (2016) sketches how in the late nineteenth century, along with urbanization, retail chains opened more and more stores, reducing the distance between consumers and their nearest outlet. The Atlantic and Pacific Tea Company, better known as A\&P, owned 16,000 stores in 1930, a number that has not been surpassed since, and making the A\&P company of the 1930s the retailer with the largest number of outlets that has ever existed. Bronnenberg and Ellickson (2015) discuss format modernization among retailers. An important development in format modernization is the increased use of convenience stores and forecourt retailing options, for example, gas station markets. These format changes also contribute to lowering the distance between (mobile) consumers and retailers.

A next retail strategy that allows consumers to economize on travel is the co-location of stores in shopping centers. Baltas et al. (2010) show that multiple-store patronage is especially attractive to consumers who value time. From the perspective of the retailer, co-location therefore attracts consumers wanting to visit multiple co-located stores at a single travel expense. An even more convenient arrangement from the vantage point of consumers than co-location is opening hypermarkets that house many departments under one roof (Messinger and Narasimhan 1997).

Next, enabling technologies like telecommunication transformed the mail-order business model first into the telemarketing companies of the 1970s. More recently, from the late 1990s onward, the continuing developments in IT and the increasing functionality of the internet as a communication, transaction, and sometimes even distribution channel, have given rise to online and e-commerce sellers. Bronnenberg and Ellickson (2015) show that this sector has faced double-digit, year-over-year growth over the past decade. Although different business models exist, most share the characteristic that they replace consumer travel cost with home delivery cost, shifting consumer time costs to retailer (or consumer) pecuniary costs of distribution. Several IT-enabled innovations in tracking and routing allow for efficient pooling of delivery across multiple customers, reducing its cost well below individual consumers driving to stores and spending time traveling. 


\subsubsection{Lowering the Purchasing Cost of Variety}

The time spent shopping for a given level of desired variety breaks down into several components; among them are (1) the time needed to locate and evaluate products and (2) the transaction and check-out time needed to fulfill the demand for variety.

Reduction in the cost of locating and evaluating market goods. Retailers are offsetting the cost of locating products in their assortment, with store navigation tools that help consumers find the product they look for. This is especially prevalent in online retail formats. IT-enabled site navigation and recommendation systems based on basket coincidence additionally help consumers to find associated items at a low cost of time (see e.g., Kim et al. 2010).

A similar system is possible for brick-and-mortar retailers provided they know the (intended) shopping baskets of their customers and can target them. For instance, as IT enabling continues, customers willing to make a shopping list may find retailers helping to minimize consumer time involved in collecting items by routing shopping trips through the store. In fact, IKEA already has close to such a system in place helping its customers finding items in its warehouse. At warehouses for Amazon Prime Now an even more advanced system is in place, where Amazon.com employees are being routed through the warehouse organized especially to collect items in a shopping basket in a timely fashion. Their IT-assisted routing through the warehouse has led to a completely different approach to stocking items. Namely, with the location of items in the warehouse known, it is no longer necessary to organize items in departments. Indeed, Amazon.com places small amounts of individual items scattered in the warehouse because "entropy" increases the chance that two items in a consumer's basket are spatial neighbors on the shelves. This has led to reductions in basket assembly time..$^{10}$ Another form of addressing shopping costs, retailers use multiple formats trying to cater to a clientele with heterogeneous preferences for travel and time (Bronnenberg and Ellickson 2015; Hortaçsu and Syverson 2015).

To reduce evaluation costs of items, an important trend in retailing has been to use so-called unit pricing guidelines to facilitate price comparisons. Since the introduction of the Fair Packaging and Labeling Act (FPLA) in $1966,{ }^{11}$ retailers in the US are required to provide a time efficient way of making price comparisons by reporting prices per volume, although the adoption of unit pricing is not uniform and is not mandatory yet in each state.

Increasingly ubiquitous over the past two decades, retailers lower evaluation costs by providing customer reviews of the products in their 
assortments (Chevalier and Mayzlin 2006). This is especially prevalent in online retailing contexts where such information is easy to collect and display.

Reduction of transaction costs. Transaction time needed to cover demand for variety rises in the number of stores and the inconvenience of checkout lines. An important retailing development in this context is the global rise in large variety retail formats (Bronnenberg and Ellickson 2015). Supermarkets replaced specialized retail formats, such as butchers, bakers, and milkmen, and eliminated separate checkout and other transaction costs for each supermarket department (Messinger and Narasimhan 1997). The most striking aspect about this trend is the dramatic increase in the variety that is being sold by a modern retailer. A recent study (Consumer Reports 2014) observes that whereas a typical supermarket carried 9,000 items in 1975, today it stocks on average 47,000 items. Such increase lowers the number stores and thus checkouts involved in purchasing variety. The trend of variety expansion is not limited to grocery items. Amazon.com sells more than 200,000 items on its website, most of which are non-grocery items, all available at a single checkout.

A second IT-enabled trend in the reduction of transaction and checkout costs consists of new payment and self-checkout systems, which reduce wait-time and idling. In several geographic markets, grocery retailers have begun self-pickup services for retailed goods, combining the convenience of online ordering and check-out with the flexibility of self-delivery often at zero or low incremental travel costs, for example, from scheduling pickups as part of commuting. ${ }^{12}$

\subsubsection{Lowering Preparation Time Through Forward Integration into Home Production}

In its 2016 outlook for the retailing industry, ${ }^{13}$ industry analyst Euromonitor concludes that trends like urbanization and aging "will contribute to a rising demand for convenience offerings by retailers." Meeting the demand for convenience means retailers inevitably will take on part of home-production by consumers. If we view the production of quantities $Z$ of consumption goods as a supply chain consisting of manufacturers, retailers, and household production, then this trend is basically a forward integration of retailers into home production. Or, more specifically, it is a trend toward retailers innovating in the direction of lowering the cost of food preparation at home, for example, through lower time costs in the conversion of market goods to consumption goods or the provision of better instructions or recipes of how to do so.

Data are clearly in line with retailers increasingly helping consumers 
to be more time efficient in food production at home. The United States Department of Agriculture (USDA) reports several examples of such a trend. ${ }^{14}$ First, there is strong growth in retailed and branded ready-to-eat goods, especially in developing countries where the level of marketization of home production is still low, but where urbanization and growing labor participation outside the home are creating a demand for timesaving food solutions. Across all countries, rich and poor, growth in the grocery channel is strongest among those categories that require little time input in home production, such as breakfast cereals and ready meals. For instance, in China the average annual growth rate for ready-to-eat breakfast cereals was 43.8 percent between 2003 and 2008. Such trends are not specific to emerging markets. Indeed, Park and Capps (1997) report a strong growth in the demand for prepared meals in the US. This growth is concentrated among younger, more educated, and more timeconstrained households.

Forward integration into home production takes on several other forms: First, retailers are selling market goods that are becoming decreasingly time intensive, that is, by selling pre-cut vegetables, pre-packaged portions, etc., as opposed to selling unprocessed foods by the pound. Second, there is a trend toward selling consumption goods and meal solutions instead of ingredients. For instance, Wholefoods sells high quality ready-to-eat meals to more affluent urban consumers with a greater willingness to pay for quality but less willingness to invest time in home production. Third, forward integration into home production may combine delivery, auxiliary services, and recipe services to reduce the time required to prepare meals. Companies such as Hello Fresh and Blue Apron do weekly home deliveries of fresh produce and meats, measured to ordered portions, along with preparation instructions, saving consumers time not only in preparation but also saving them time prospecting for new recipes. More traditional retailers are experimenting with similar services.

In sum, retailers shift household time allocations to selling cost not only by reducing the total time cost of travel and purchasing - as seen in the previous two subsections - but also by changing their assortment to include more convenience products. 


\subsection{RELATED TRENDS IN MANUFACTURING}

\subsubsection{Manufacturer Responses to Changes in Home Production Costs}

Higher consumer demand for convenience not only affects retailers but also manufacturers. Manufacturers have an incentive to act consistently with retailers' goals, for example, by providing convenient market goods that allow retailers to compete more effectively. In addition, given distribution, manufacturers have an incentive to attract consumers and produce varieties that lower the cost of a unit of utility, for example, by producing varieties that cost less time or money in terms of home production.

Using the taxonomy of fixed cost in home production proposed in section 3, in this section, I highlight how manufacturers respond to changes in the consumer cost of travel, the cost of evaluation, and the cost of food preparation.

\subsubsection{Manufacturer Responses to the Reduction of Travel Costs}

The reduction of travel costs has two opposing effects on manufactured variety. First, when retailers lower the consumers' distance of travel by entering more densely in the market, more of them will enter and per-store profits will likely drop. If, store entry costs are additionally increasing in the variety of assortment carried, then a likely consequence of having a dense retail network is that stores use a limited variety format. This may ultimately have negative consequences for how much variety manufacturers produce.

If technology lowers the cost of travel per unit of distance, this enables consumers to travel greater distances at the same cost and thus makes it possible for retailers to compete for larger trade areas. This retail competition over larger trade areas fosters the entry of "big box" stores, carrying larger assortments. Ultimately, this expansion of variety in assortment creates opportunities for more product introductions and innovations by manufacturers (see, e.g., Bronnenberg 2017)

Migrating retail to an online transaction channel reduces the time cost of travel for consumers even further. Per consequence, online retailers have access to very large trade areas. Also, the cost of stocking variety in their warehouses is low compared to the cost of variety in urban areas and upscale stores. Such conditions foster the emergence of a retail sector with few retailers selling very large assortments. To manufacturers, even products with low per-household demand can thus become a viable venture because of the access to large sales territories through only a few retailers. 
It is therefore expected that this leads to more niche products and more diversity in manufacturing.

Both opposing forces are active and we observe at the same time a rise in limited format retailers as well as large assortment options. This serves a population heterogeneous in their value for time versus income.

\subsubsection{Manufacturer Responses to Reduction of Consumer Purchasing Costs of Variety}

By lowering the time cost of purchasing variety, retailers have raised consumers' demand for variety. In the previous section, I argued that competing retailers met this rising demand for variety by expanding the variety of their assortment dramatically. Although the retailer's procurement of variety can partly be accomplished through trade, innovation by manufacturers is another important source of assortment variety expansion.

Figure 1.3 shows data from the Economic Research Bureau of the United States Department of Agriculture representing the number of new

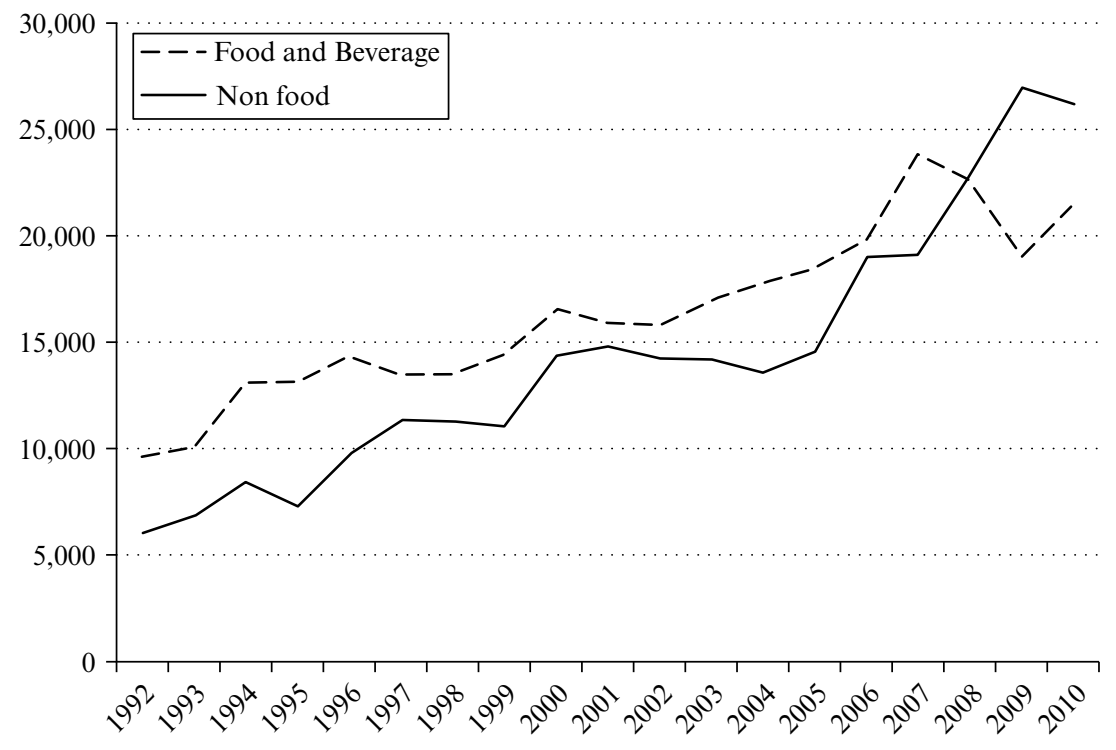

Notes: Calculated by Economic Research Service (ERS) of the United States Department of Agriculture (USDA), available at https://www.ers.usda.gov/mediaImport/961983/new product.xls.

Figure 1.3 New product introductions of consumer packaged goods, 1992-2009 
products launched in the United States in recent decades. As can be seen from this graph, the number of new products launched by manufacturers increased strongly over the 19 years between 1992 and 2010, with a compound annual growth rate (CAGR) of 4 percent in food items and 8 percent in non-food items. Whereas there may also be other technological reasons contributing to this increase, reducing market frictions by offering variety to consumers at a low time cost of purchasing raises the demand for variety, and along with it, gives scope for more supply (see e.g., Bronnenberg 2017).

\subsubsection{Manufacturing Responses to Reduction of the Time Cost in Preparation of Foods at Home}

As reported in Bronnenberg et al. (2017), consumers shift their consumption to convenience goods when they are more time-constrained. The demand for food items for such consumers has migrated from traditional time-intensive (versions of) foods to ready-to-consume versions and retailers compete for this consumer demand. Most manufacturers cannot sell direct to the end consumer and therefore must incorporate the retailers' attempts to win the urban time-strapped consumer with convenience into their own strategic actions. This motivates them to manufacture goods to keep the time input into home production low. They do so by making and selling more ready-to-eat foods.

The Food and Drug Administration (FDA) defines ready-to-eat foods as being consumable directly or after heating. New York-based market researchers Future Market Insights predict that the ready-to-eat food category will grow at a CAGR of 7.2 percent globally for 2016-2026, from US\$52.1 billion to US\$195.3 billion. ${ }^{15}$ The Nielsen Company presented a study ${ }^{16}$ in 2014 on purchasing habits of consumers and concluded that "Assembling but not fully preparing meals is a popular trend among a growing number of shoppers who want to be involved with food preparation but also have much of the work done for them." Table 1.3 shows the fastest growing grocery food categories for 2016 in consumer packaged goods using data provided by the Nielsen Company. ${ }^{17}$ Without exception, the topranked categories all represent ready-to-eat options. This supports that the composition of the manufactured variety is changing in the direction of forward integration into home production and ready-to-eat food productions.

This direction of innovation is further consistent with demand for market goods from an aging and more affluent population, willing to pay for convenience, and therefore being an attractive segment for manufacturers and retailers who can ask higher prices for products with lower time cost. Becker's (1965) theory already predicted these trends simply from 
Table 1.3 Fastest growing food categories in consumer packaged goods by dollar sales

\begin{tabular}{lc}
\hline Category & 2016 dollar sales growth rate \\
\hline Refrigerated breakfast entrée & $82.3 \%$ \\
Frozen gravy and sauce & $42.2 \%$ \\
Frozen meal starters & $33.6 \%$ \\
Refrigerated appetizer & $27.2 \%$ \\
Liquid tea & $19.8 \%$ \\
Sushi & $16.1 \%$ \\
Liquid coffee & $14.2 \%$ \\
Lunch combination & $13.8 \%$ \\
\hline
\end{tabular}

Source: Nielsen data for fastest-growing food and beverage categories with more than $\$ 10$ million in sales in the 52 weeks leading up to October 29, available at http://www.fooddive. com/news/convenience-food-sales-growth-2016/433092/.

life-cycle dynamics in time and income, and from demographic shifts in the population.

\subsection{CONSEQUENCES OF CHANGES IN RETAIL TECHNOLOGY}

\subsubsection{Effects of Distribution on Household Time Allocation}

So far, this chapter has addressed how increased valuation for convenience by consumers and IT-related technology shocks have compelled retailers and manufacturers to provide more convenience to consumers and improve household productivity of food purchases and preparation. With currently 20 percent of consumers' time use tied up in shopping, food preparation, and food consumption, in this section I want to circle back to the beginning of this chapter and ask how consumer behavior adjusts in response to such strategies. I address this question by reviewing the empirical literature on how households' time use adjusts to a marginal time endowment. Since this literature is quite large, I organize the discussion of it along the three margins of household time use adjustment considered in the new consumer theory: leisure, labor (or income), and (variety in) home production. Do household members spend retailer-induced time savings on more leisure? Will they use them to spend more time in the labor market and earn more income? Or, are they going to use the time savings to adjust their home 
production to a larger variety or to more time/less money intensive consumption goods?

\subsubsection{Impact on Leisure}

Gronau (1977) was among the first to study how consumers make trade-offs between leisure, labor in the market, and labor at home. He presents a model that predicts how income (including non-work income) increases leisure at the expense of work time in the market but leaves home production unchanged. At the same time, wages (income from work) increase work time in the market but its effects on leisure and home production are indeterminate. Empirical support for these predictions is also presented. Aguiar and Hurst (2007a) show that household time allocation to leisure has increased substantially between 1965 and 2003 . One reason behind this decrease is the marketization of home production. Aguiar and Hurst (2007a) report that average hours worked per week for non-retired consumers stayed essentially constant. However, the average hours of non-market work has shrunk considerably. For example, women increased leisure by almost 5 hours a week, whereas work in home production decreased by 10 hours a week. Men increased leisure by more than 6 hours.

Together these studies suggest that the time endowment from marketization of home production has led to more consumption of leisure, although it is also possible that some home production of food has become leisure for some consumers.

\subsubsection{Impact on Income}

Marketization of home production has not only affected leisure, but also labor participation. Using a cross-sectional data set, Freeman et al. (2005) observe there is a large gap in hours worked between the United States and the European Union. For instance, in 2002 a US laborer worked on average 1305 hours a year, whereas a German worker 932 per year. Historically this difference and others like it have been linked to different labor market institutions, for example, centrally negotiated labor contracts, lay-off protection, etc. However, Freeman et al. (2005) and Van Ark et al. (2008) present the hypothesis that the difference is also caused by different levels of marketization of home production in the US versus Europe, especially in the provision of foods and childcare. Evidence from time use data shows that the correlation between market and household work is strongly negative, especially for women. In a related study, Biddle and Hamermesh (1990) find that household mem- 
bers even trade sleep for labor. In particular, they report that time spent sleeping is inversely related to wages and time spent working outside the home.

Solberg and Wong (1992) report how shifts in work commute time impact time use and labor participation substantially. Relatedly, Bertrand and Kramarz (2002) study how supermarket entry and replacement of traditional retail formats impact labor supply. They find that free entry in a modern retail sector is associated with more women joining the labor market, both in retail and beyond it. Ngai and Pissarides (2008) study economic growth and labor supply. They too report that the marketization of home production has led to more labor participation, especially among women. Rogerson (2008) discusses the impact of different levels of marketization of home production for labor market outcomes in the United States and Europe. He focuses on asymmetrically taxing income (money) but not time. This has the consequence of making income scarce relative to time. Comparing tax regimes in Europe with those in the United States, he concludes that labor markets in Europe have suffered from taxing income more. This creates a relative abundance of time in Europe, comparatively blocking the development and growth of service sectors that replace home production.

All these studies point to the same underlying theme, namely that providing more convenience and marketization of home production has led to (partial) substitution into the labor market and ceteris paribus, more income.

\subsubsection{Impact on the Variety and Nature of Home Production}

Finally, I consider the impact of time shocks on the variety and nature of home production. Aguiar et al. (2013) study the substitution of time and money in home production, using economic downturns as a natural experiment. They find that time available from foregone market work is reallocated to home production ( 30 percent) and leisure (50 percent). Gronau and Hamermesh (2008) study the effect of wages and non-work income on household members' time use and variety in home production. They find that increases in wages, income, and schooling have a positive impact on the variety of home production.

In the study quoted in the previous paragraph, Aguiar et al. (2013) find that, of the 30 percent of foregone work hours reallocated to home production, 7 percent of foregone work hours are used as additional shopping time. Aguiar and Hurst (2007b) report that a change in the availability of time, that is, from retirement, is positively associated with allocating more 
time to shopping and paying lower prices (which is a substitution of time for money in home production). ${ }^{18}$

In the same context of the effects of retirement, Bronnenberg et al. (2017) show evidence that changes in the availability of time in a household have a strong impact on the amount of home production that households do and the amount of variety in the market goods they buy. On the other hand, Pozzi (2012) finds that the convenience of repeat ordering the same shopping list at a single click online, leads consumers to explore fewer varieties online than in the store. Taken together, these studies show evidence that the availability of additional time leads to more home production, and typically to more variety in purchasing behavior.

In sum, sections 5.2-5.4 present empirical evidence that changes in the amount of time required for domestic output, brought on by marketization of home production or technology shocks over the past decades, have increased household leisure, increased labor participation, and increased variety in home production.

\subsection{RESEARCH OPPORTUNITIES AND CONCLUSIONS}

Becker (1965) started an important scholarly debate on the role of time allocation and time cost in household consumption decisions. Whereas the effects of income are well studied in the quantitative marketing literature on product choice, consumption, and purchasing patterns, the role of time cost and convenience is not yet a debate at the core of research in marketing. Thus, the effects of household time budgets are often left unmeasured in marketing and ultimately remain absent from the analysis of household consumption decisions. This hinders assessment of the benefits of marketing institutions intended to make home production more efficient and promotes a focus on just their costs. Consistent with the productive and more optimistic view on marketing espoused in the early management literature (e.g., Drucker 1954) however, the benefits of marketing in producing convenience and product variety in home production are likely substantial.

With respect to the retail sector, one cannot hope to fully address fundamental questions of the value added by the retail sector, its productivity, and its impact on welfare without taking into account the retail sector's role in the marketization of home production. Therefore, time use and the time cost of home production should be at the forefront of a research agenda assessing the added value and functions of retailing.

Among the important research themes in such an agenda would be to 
measure how much consumers value leisure and time savings relative to the consumption of goods. Another theme would be to investigate not just the value of time savings that are brought on by marketization of home production of consumption goods, but also the value of being able to allocate time flexibly. Finally, it will be important to study where to put the border between production in the retail channel and production at home from a societal perspective (see also, e.g., Freeman et al., 2005) and how close market institutions approximate the welfare ideal.

\section{NOTES}

1. See, https://unstats.un.org/unsd/snaama/introduction.asp for a full overview of available data tables.

2. In particular, Brazil, Russia, India, and South Korea.

3. Shaw (1990) covers an extensive literature overview on the cost of distribution.

4. See https://www.h5.scb.se/tus/tus/Default.htm.

5. Bertrand and Schanzenbach (2009) additionally report that time spent on eating meals as a primary activity.

6. For a more elaborate introduction to Becker (1965), see Chiappori and Lewbel (2015). For a related history of research on households and home production, also predating Becker (1965), see Heckman and Sattinger (2015).

7. One consequence of this is that the demand for market goods depends on household productivity. Also therefore, the full (pecuniary and time) price of consumption goods depends on household expertise in home production, even if households all pay the same price for market goods at the checkout.

8. The cost of preparation of food is obviously not fully fixed to quantity but also contains variable components.

9. The earliest debate about institutions shifting the consumers' cost of distribution and using the market to specialized tradesmen, to my knowledge at least, is Plato's Republic (translation by Bloom, 1991, see Book II, 371).

10. See https://en.wikipedia.org/wiki/Mail_order.

11. See http://www.businessinsider.com/inside-amazon-warehouse-2016-8? international=t rue\& $\mathrm{r}=\mathrm{US} \& \mathrm{IR}=\mathrm{T}$.

12. See https://www.nist.gov/sites/default/files/documents/2017/04/28/SP1181-Unit-Pricing -Guide.pdf.

13. See, for example, https://www.kroger.com/onlineshopping/pickstore for an example of consumers being able to select their pickup location.

14. See http://go.euromonitor.com/rs/805-KOK-719/images/wpNewConceptsRetailing201 6.pdf.

15. See https://www.ers.usda.gov/topics/international-markets-trade/global-food-markets/ international-consumer-retail-trends/.

16. http://www.futuremarketinsights.com/reports/ready-to-eat-food-market.

17. http://www.nielsen.com/us/en/insights/news/2014/convenience-its-whats-for-dinner-ton ight.html.

18. Because the value added from time inputs in home production is not part of expenditures, the value of consumption goods exceeds expenditure on market goods in the store, and it does so more for older consumers. 


\section{REFERENCES}

Aguiar, M., and Hurst, E. (2007a), "Life-Cycle Prices and Production," The American Economic Review, 97(5), 1533-1559.

Aguiar, M., and Hurst, E. (2007b), "Measuring Trends in Leisure: The Allocation of Time over Five Decades," The Quarterly Journal of Economics, 122(3), 969-1006.

Aguiar, M., Hurst, E., and Karabarbounis, L. (2013), "Time Use During the Great Recession," The American Economic Review, 103(5), 1664-1696.

Balasubramanian, S. (1998), "Mail versus Mall: A Strategic Analysis of Competition between Direct Marketers and Conventional Retailers," Marketing Science, 17(3), 181-195.

Baltas, G., Argouslidis, P. C., and Skarmeas, D. (2010), "The Role of Customer Factors in Multiple Store Patronage: A Cost-Benefit Approach," Journal of Retailing, 86(1), $37-50$.

Becker, G. S. (1965), “A Theory of the Allocation of Time,” The Economic Journal, 75(299), 493-517.

Bell, D. R., Ho, T.-H., and Tang, C. S. (1998), "Determining Where to Shop: Fixed and Variable Costs of Shopping," Journal of Marketing Research, 35(3), 352-369.

Bertrand, M., and Kramarz, F. (2002), "Does Entry Regulation Hinder Job Creation? Evidence from the French Retail Industry," The Quarterly Journal of Economics, 117(4), 1369-1413.

Bertrand, M., and Schanzenbach, D. W. (2009), "Time Use and Food Consumption," The American Economic Review, 99(2), 170-176.

Betancourt, R. R. (2004), The Economics of Retailing and Distribution. Edward Elgar Publishing, Cheltenham.

Biddle, J. E., and Hamermesh, D. S. (1990), "Sleep and the Allocation of Time," Journal of Political Economy, 98(5), 922-943.

Bloom, A. (1991), The Republic of Plato. HarperCollins, New York.

Braithwaite, D., and Dobbs, D. B. (1932), The Distribution of Consumable Goods. Routledge, London and New York.

Bronnenberg, B. J. (2015), "The Provision of Convenience and Variety by the Market RAND," Journal of Economics, 46(3), 480-498.

Bronnenberg, B. J. (2017), "Innovation and Distribution: A General Equilibrium Model of Manufacturing and Retailing," working paper.

Bronnenberg, B. J., and Ellickson, P. B. (2015), "Adolescence and the Path to Maturity in Global Retail," Journal of Economic Perspectives, 29(4), 1130-1134.

Bronnenberg, B. J., Klein, T. J., and Xu, Y. (2017), "Time Availability and Purchase Behavior," working paper.

Buera, F. J., and Kaboski, J. P. (2012), "The Rise of the Service Economy," The American Economic Review, 102(6), 2540-2569.

Chevalier, J. A., and Mayzlin, D. (2006) "The Effect of Word of Mouth on Sales: Online Book Reviews," Journal of Marketing Research, August, 43(3), pp. 345-354.

Chiappori, P.-A., and Lewbel, A. (2015), "Gary Becker's A Theory of the Allocation of Time," The Economic Journal, 125(583), 410-442.

Consumer Reports. (2014), "What to Do When There Are Too Many Product Choices on the Store Shelves?," Consumer Reports Magazine (March).

Cutler, D. M., Glaeser, E. L., and Shapiro, J. M. (2003), "Why Have Americans Become More Obese?," The Journal of Economic Perspectives, 17(3), 93-118.

Dixit, A. K., and Stiglitz, J. E. (1977, June), "Monopolistic Competition and Optimum Product Diversity," American Economic Review, 67(3), 297-308.

Drucker, P. F. (1954), The Practice of Management. HarperCollins, New York.

Ellickson, P. B. (2016), "The Evolution of the Supermarket Industry: From A\&P to Walmart," in E. Basker (ed.) Handbook on the Economics of Retail and Distribution, Edward Elgar Publishing, Cheltenham, pp. 368-391.

Freeman, R. B., Schettkat, R., Duflo, E., and Jappelli, T. (2005), "Marketization of Household Production and the EU-US Gap in Work," Economic Policy, 20(41), 7-50. 
Gronau, R. (1977), "Leisure, Home Production, and Work - the Theory of the Allocation of Time Revisited," Journal of Political Economy, 85(6), 1099-1123.

Gronau, R., and Hamermesh, D. S. (2008), "The Demand for Variety: A Household Production Perspective," The Review of Economics and Statistics, 90(3), 562-572.

Hamermesh, D. S., Frazis, H., and Stewart, J. (2005), "Data Watch: The American Time Use Survey," The Journal of Economic Perspectives, 19(1), 221-232.

Heckman, J. J., and Sattinger, M. (2015), "Introduction to The Distribution of Earnings and of Individual Output, by A.D. Roy," The Economic Journal, 125(583), 378-402.

Hortaçsu, A., and Syverson, C. (2015), "The Ongoing Evolution of US Retail: A Format Tug-of-War," Journal of Economic Perspectives, 29(4), 89-112.

Huang, Y., and Bronnenberg, B. J. (2017), "Pennies for Your Thoughts: Costly Product Consideration and Purchase Quantity Thresholds," working paper.

Johnson, R. N., and Romeo, C. J. (2000), "The Impact of Self-Service Bans in the Retail Gasoline Market," The Review of Economics and Statistics, 82(4), 625-633.

Kim, J. B., Albuquerque, P., and Bronnenberg, B. J. (2010), "Online Demand Under Limited Consumer Search," Marketing Science, 29(6), 1001-1023.

Malenbaum, W. (1941), "The Cost of Distribution," The Quarterly Journal of Economics, 55(2), 255-270.

Messinger, P. R., and Narasimhan, C. (1997), "A Model of Retail Formats Based on Consumers' Economizing on Shopping Time," Marketing Science, 16(1), 1-23.

Ngai, L. R., and Pissarides, C. A. (2008), "Trends in Hours and Economic Growth," Review of Economic Dynamics, 11(2), 239-256.

Park, J. L., and Capps, O. (1997), "Demand for Prepared Meals by U.S. Households," American Journal of Agricultural Economics, 79(3), 814-824.

Pozzi, A. (2012), "Shopping Cost and Brand Exploration in Online Grocery," American Economic Journal: Microeconomics, 4(3), 96-120.

Pryor, F. L. (1977), "Some Costs and Benefits of Markets: An Empirical Study," The Quarterly Journal of Economics, 91(1), 81-102.

Rogerson, R. (2008), "Structural Transformation and the Deterioration of European Labor Market Outcomes," Journal of Political Economy, 116(2), 235-259.

Shaw, A. W. (1912), "Some Problems in Market Distribution," Quarterly Journal of Economics, 26(4), 703-765.

Shaw, E. H. (1990), "A Review of Empirical Studies of Aggregate Marketing Costs and Productivity in the United States," Journal of the Academy of Marketing Science, 18(4), 285-292.

Solberg, E. J., and Wong, D. C. (1992), "Family Time Use: Leisure, Home Production, Market Work, and Work Related Travel," The Journal of Human Resources, 27(3), 485-510.

van Ark, B., O’Mahony, M., and Timmer, M. P. (2008), "The Productivity Gap between Europe and the United States: Trends and Causes," The Journal of Economic Perspectives, $22(1), 25-44$. 